\title{
"Betekenis" en "Gebruik" in die Makarismereeks (Matt 5:3-10)
}

\author{
A G v AARDE
}

Daar was ' $n$ tyd in die strukturele taalkunde toe daar gereken is dat die ontleding en beskrywing van taalgebruik en die inhoud daarvan slegs ' $n$ saak is van om woorde in terme van ander woorde, sinne in terme van ander sinne, ensovoorts te probeer verklaar en nie in terme van ook buite-linguistiese fenomene nie, soos byvoorbeeld die situasie waarin taalgebruik ontstaan. Dit wil sê, inhoudsbepaling was alleen 'n saak van die immanent-sintaktiese en outosemantiese struktuurontleding en -beskrywing. Die inhoud van taalgebruik is daarom beskou as ' $n$ tweeledige referensiële verhouding van 'n teken (lekseem, lekseemkombinasie, kolon, perikoop, ensovoorts) en 'n objek. Later was hierdie beskouing vir baie taalkundiges nie meer presies genoeg nie. Die situasie waarin taalgebruik ontstaan moet bykom. ${ }^{1}$ Hierdie taalgeleerdes wys daarop dat taalgebruik nie in 'n vakuum ontstaan nie. Daar moet met die interrelasie van spreker/outeur èn hoorder/leser èn taaltekens rekening gehou word. Eersgenoemde twee sluit reeds implisiet die situasie in tyd en historie in. Daar moet dus op die semantiese vlak onderskeid gemaak word tussen wat genoem word die taalteken en sy betekenis en die taalteken en sy gebruik. Dit is hierdie linguistiese kategorie "gebruik" wat in 'n baie groot mate te make het met die situasie waarin 'n spreker/outeur taaltekens soos lekseme, lekseemkombinasies en sinne gebruik om met sy hoorder/leser te kommunikeer. Die situasie waarin die outeur en/of die leser hom bevind, kan veroorsaak dat van die lekseme, lekseemkombinasies en sinne na'n objek verwys of dit impliseer wat nie suiwer die leksikaliese "betekenis" van die lekseme of hulle kombinasies is nie. Die verskynsel verwysing en impli$k a s i e$ kan aan die hand van die volgende twee voorbeelde geillustreer word:

In Handelinge 27:17 kom die lekseem boètheia voor. Die 1933-Afrikaanse vertaling het hierdie lekseem in ooreenstemming met sy leksikaliese betekenismoontlikheid as "hulpmiddel" weergegee. Die Good News Bible se weergawe daarvan is "ropes". Die 1979-Afrikaanse vertaling bevat ook die vermelding van "toue". In sommige woordeboeke word die leksikaliese betekenis van boëtheia inderdaad dan ook foutiewelik as "tou" of "kabel" aangegee deurdat die onderskeid tussen betekenis en verwysing nie gemaak word nie. In die konteks en situasie van Handelinge 27:17 is die "hulpmiddel" wat ter sprake is, waarskynlik wel "toue". Dit wil egter nie sê dat "toue" 
'n leksikaliese betekenismoontlikheid van boētheia is nie. In die situasie word boëtheia slegs gebruik as verwysing na "toue".

In Handelinge 7:24 kom die lekseem patassō voor. Die leksikaliese betekenis van dié lekseem is in die konteks daar die interpersoonlike gebeure van "om te slaan". Vanweë die situasie in tyd, historiese en tradisie weet ons egter dat die "slaan" daar "doodslaan" impliseer. Die 1979-Afrikaanse vertaling gee dat ook hierdie implikasie weer. Dit is korrek om dit so te vertaal, maar dan moet ons onthou dat "doodslaan" nie die leksikaliese betekenis van patassō is nie, maar slegs die implikasie daarvan in die situasie.

Vir die uiteindelike verstaan van die geheelinhoud van bepaalde taalgebruik is dit daarom van groot belang om ook aan die semantiese kategorie "gebruik" naas dié van "betekenis" aandag te gee. Daar is dus ' $n$ groot mate van waarheid geleë in die woorde van die bekende taalfilosoof $\mathrm{L}$ Wittgenstein: "Don't look for the meaning, look for the use". ${ }^{2}$ Vir die eksegese van die Bybel in sy geskeie, maar onafskeibare tweeledigheid van Ou Testament en Nuwe Testament, is hierdie belang nog vanselfsprekender. Die verskillende Bybelboeke het inhoudelik ' $n$ onlosmaaklike band met mekaar. Hierdie band is daar vanweë onder andere die inhoudelike verwysings of implikasies met betrekking tot kronologiese ontwikkelinge van soteriologiese tradisies vanaf die Ou Testament na en deur die Nuwe Testament. ${ }^{3}$ Die inhoud van ' $n$ bepaalde Bybelboek of gedeelte daarvan kan nouliks sonder die inagneming van dié tradisieraakpunte verstaan word. Deurdat die eksegeet die kategorie "gebruik" wat dikwels diakronies bepaald is, by die sinkroniese sintakties-stilisties-semantiese ondersoek betrek, kan hy die nodige aandag aan die tradisiehistoriese aspekte van die teks gee.

Om die kategorie "gebruik" op 'n wetenskaplik-kontroleerbare wyse in terme van die sintakties-stilisties-semantiese struktuur van die teks te beskryf, is 'n moeilike taak. Wat antieke literatuur soos die Bybel betref, is dié taak nog baie moeiliker as gevolg van die afstand wat daar bestaan tussen die eksegeet en die situasie waarin die teks ontstaan het. Die situasie mag egter nie die wegspringplek vir die eksegese wees nie. Die indra van ongekontroleerde irrelevante buitetekstuele gegewens kan lei tot inlegkunde pleks van eksegese. Dit is een van die slaggate waarin die historiese kritiek kan val. Ek het daarom begrip vir geleerdes soos W S Vorster ${ }^{4}$ wat van mening is dat die historiese kritiek nie deel van die eksegetiese proses is nie. Onder historiese kritiek word die verskillende tradisionele metodes verstaan soos Quellenforschung, Formgeschichte, Überlieferungsgeschichte en Redaktionsgeschichte. Vorster is van mening dat hierdie metodes slegs kan bydra om die eie-aard van die Bybelse tekste in hulle taal-, vorm-, tradisie-, godsdiens-, verkondi- 
ging- en geloofsgeskiedkundige aspekte te herken. Al hierdie aspekte hou dus alleen verband met die wording van die teks en kan volgens Vorster nie ' $n$ antwoord bied op die vraag na die intensie van die teks nie. Die historiese kritiek behoort daarom volgens hom tot die voorarbeid vir die eksegese. Hy maak ter verduideliking van sy beskouing gebruik van 'n aanhaling van W Richter: "Die Wahl der Fragestellung bestimmt das Vorgehen." ${ }^{5}$ Nieteenstaande die baie waarheidselemente van só ' $n$ benadering, kan Vorster se siening met betrekking tot die historiese kritiek as "voorarbeid" nie sonder meer aanvaar word nie. Deur gebruik te maak van 'n soortgelyke beroep op woorde uit dieselfde bladsy van Richter se boek, sal ek vervolgens aantoon hoe die resultate van die historiese kritiek in die eksegese verwerk kan word met honorering van wat die linguistiek ons leer èn sonder die indra van buitetekstuele gegewens: "Die Fragestellungen müssen innerhalb des Rahmens bleiben, den die formale Analyse errichtet hat."

Die historiese kritiek is myns insiens wel 'n wyse van eksegese, hoewel dit as metodemonisme by verre onvoldoende is. Een van die belangrikste bydraes van hierdie hoofsaaklik diakroniese manier van ondersoek, is die verheldering van die intensie van die outeur/ redaktor en van die Sitz im Leben/Sitz in der Literatur van ' $n$ betrokke Bybelgedeelte. ${ }^{6}$ Sodanige resultate is vir die inhoudsbepaling van historiese tekste soos Bybelpassies onmisbaar. Dit dui naamlik elemente aan van die situasie waarin 'n teks ontstaan het. Ek het vroeër aangetoon dat die situasie as een van die geïntegreerde aspekte van betekenisvolle taalgebruik beskou moet word. Vir die verheldering van die situasie bly die historiese kritiek tot op datum die enigste metode vir die verkryging van die beste resultate. Om 'n verval in "diakronisme" te voorkom, moet die relevante resultate van die historiese kritiek kontroleerbaar in die proses van die sinkroniese sintakties-stilisties-semantiese struktuuranalise ingebou word. Die metodepluralie wat ondersoekers soos Richter, Fohrer cs en Loader ${ }^{7}$ voorstel, kan egter nie aanvaar word nie. Dit is 'n metodologiese benadering waarin die tradisionele histories-kritiese fasette bloot agter in die ry geplaas word van die streng-opeenvolging van "Ebenen" wat by die perikoopafgrensing begin en by die "zusammenfassende Exegese" eindig. ${ }^{8}$ Die histories-kritiese ondersoek moet afsonderlik van die sinkroniese aandag kry en moet nie bloot as ' $n$ fasset agter in die ry van die sinkroniese beskou word nie. Die relevante resultate van die histories-kritiese ondersoek moet dan in die proses van die semantiese analise ingevul word. Dit kan geskied deur die kategorie "gebruik" sy regmatige rol te laat speel. Net soos die sintakties-stilistiese struktuuranalise die kontrolerende raamwerk vir die semantiese invulling is, geld dit ook as die raamwerk vir die gebruikmaking van die kategorie "gebruik". Sodoende bied 
die sinkroniese ondersoek die beskerming teen 'n willekeurige verval in "diakronisme".

Die artikel sal poog om met behulp van die makarismereeks in Matteus 5 as illustrasiemateriaal' ' $n$ metodologiese oefening te bied in die lig van my uiteensetting hierbo. Die sintakties-stilistiese analise is die ontleding en beskrywing van die oppervlaktestruktuur. Die semantiese analise is die ontleding en beskrywing van die dieptestruktuur. Aan die einde sal die resultaat van die ondersoek vanuit enkele gesigspunte saamgevat word.

\section{Die Oppervlaktestruktuur}

In hierdie afdeling van ons ondersoek word die perikoop afgebaken en 'n struktuuranalise daarvan gedoen. Vervolgens word die posisie van die betrokke perikoop in sy nouer en breër konteks geplaas. By die bespreking van die struktuuranalise van die nouer en breër konteks sal noodwendigerwys aan inhoudelike aspekte aandag gegee word om sodoende die posisie van die perikoop onder bespreking in reliëf te plaas.

\section{Perikoopafgrensing}

In Matteus 5:3-10 het ons 'n reeks van nege uitsprake wat begin met die woord makarioi. Die eerste agt is gevorm op ' $n$ identiese patroon. Die makarisme is in die derde persoon, gevolg deur ' $n$ hotibysin. Elke bysin is bondig en die eerste en agtste is presies dieselfde, naamlik hoti autōn estin hē basileia tōn ouranōn. Die negende uitspraak is anders. Hierdie makarisme is in die tweede persoon meervoud geformuleer. Verder vind ons hier, in teestelling tot die ander, meer gegewens in 'n temporele bysin, gevolg deur wat oënskynlik 'n herhaling van die makarisme is, net in 'n ander vorm, naamlik chairete kai agalliasthe. Dan volg daar 'n hoti-bysin wat op sy beurt verder ondersteun en uitgewerk word deur ' $n$ addisionele garbysin. Die feit dat die negende uitspraak in die tweede persoon geformuleer is, in teenstelling met die derde persoon van die eerste agt, maak hierdie uitspraak reeds los van die eerste agt. En as dit verder ook nie inpas by die parallelistiese patroon van die eerste agt nie, laat dit ons baie sterk vermoed dat ons ' $n$ wending in die perikoop van vs 11 af kry. Dit blyk dat vss 3-10'n eenheid is en vss 11-12 'n oorgang na die volgende deel van die Bergrede. 
kai anoixas to soma autou edikasken autous legōn

.1 Makarioi hoi ptōchoi tō pneumati,
hoti autōn estin hē basileia tōn ouranōn.
A .2 makarioi hoi penthountes,
hoti autoi paraklēthēsontai.
.3 makarioi hoi praeis
hoti autoi klēronomēsousin tēn gēn.
.4 makarioi hoi peinōntes kai dipsōntes tēn dikaiosunēn,
hoti autoi chortasthēsontai.

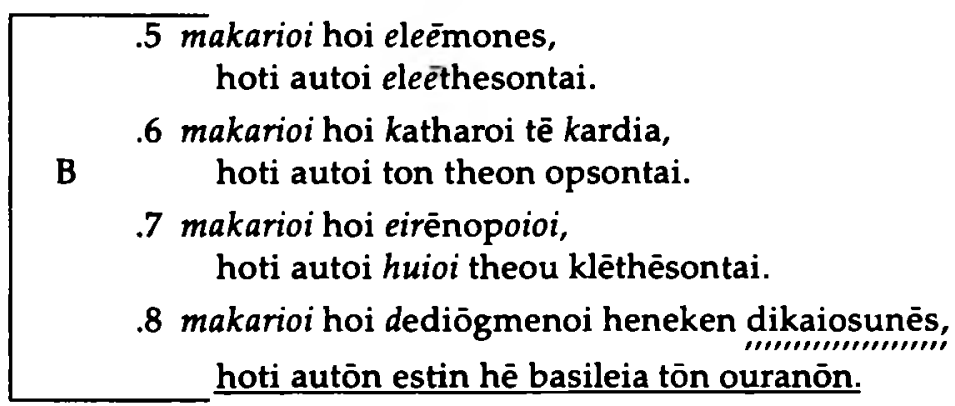

Streng gesproke moet Matteus 5:2-7:27 as een kolon opgeneem word waarin 5:3-7:27 die direkte rede na die semantiese eenheid kai anoixas to stoma autou edidasken autous legoñ vorm. Vir die doel van ons analise word die parataktiese sinskonstruksies binne die direkte rede subkola genoem, en dit word numeries aangedui met .1, .2, .3, ensovoorts. Die struktuur vertoon die eienskappe soos dit tipies binne narratiewe materiaal voorkom. Die relasies van die verskillende kola tot mekaar is naamlik liniêr van aard, en dit is dus nie nodig om dié relasies hier met verbindingslyne aan te toon, of om die kommata af te merk nie. Slegs die relasie van die twee kolongroepe (= "clusters"), A en B, word aangetoon.

Die struktuuranalise bevestig die breuk tussen subkolon .8 en die daaropvolgende. Behalwe die wisseling van die derde na die tweede persoon, wat alreeds ' $n$ breuk aandui, is die herhaling van die bysin van subkolon .1 in subkolon .8 inklusief. Dit bevestig die breuk. Daarbenewens word die skeiding tussen subkola .8 en die daaropvolgende ook duidelik vanweẽ die stilistiese verskille tussen .1 tot .8 en wat daarop volg. 
Die eerste wat opval, is die anaforiese patroon binne die eerste agt subkola, bestaande uit makarioi plus 'n substantief of 'n adjektief met die artikel hoi. Verskeie navorsers ${ }^{10}$ het die aandag op bepaalde rymklank binne die onderhawige konteks gevestig. Dit is die tweede saak wat opval, naamlik dat daar 'n alliterasie-assonansie-paronomasia skema binne die anaforiese passasie bestaan (vergelyk hierbo waar die alliterasie, assonansie en paronomasia in die struktuuranalise kursief gedruk is). Alliterasie, assonansie en paronomasie is veral karakteristieke elemente van die Semitiese poësie. ${ }^{11}$ Dit beklemtoon die Grieks-Semitiese skryfstyl wat in die Matteusevangelie aangetref word.

Omdat ' $n$ anafoor egter in homself ' $n$ natuurlike fonetiese alliterasie of assonansie bevat ${ }^{12}$, moet ons versigtig wees om nie rymklank wat eiendomlik aan die anafoor gebonde is, as struktuurmerkende argumente te gebruik nie. Dit laat dus die alliterende $m$ van makarioi en die assonerende hoi in die daaropvolgende artikel as merkers buite rekening. Die $p$-alliterasie in die eerste vier subkola kan egter nouliks toevallig wees (vergelyk ptōchoi, penthountes, praeis en peinōntes). Dit geld inderdaad ook vir die skema binne die individuele subkola self, naamlik die dubbel $p$ in subkolon .1 en subkolon $.4^{13}$, die dubbel $d$ in subkolon .4 sodat ons in hierdie subkolon die parallelisme het van $p \ldots d \ldots p \ldots d$, die dubbel $e$ in subkolon .5, die dubbel $k$ in subkolon .6, en die dubbel $d$ in subkolon .8. In die orige subkola van die anafoor vind ons verdere aanduidinge van só 'n skema. Die $k$ van klêronomēsousin en die $g$ van $g \bar{e} n$ in subkolon .3 is albei velere plosiewe (eersgenoemde stemloos, en laasgenoemde stemhebbend), en daarom kan ons hier ten minste van semi-alliterasie praat. ${ }^{14}$ In subkolon .7 het ons in die ei van eirénopoioi en die hui van huioi gelykluidende diftonge wat ons semi-assonansie kan noem. In hierdie selfde subkolon vind ons ook nog ' $n$ verdere assonansie, naamlik die oi wat twee keer in eirènopoio $i^{15}$ voorkom, sowel as in huioi. In die gebruik van die lekseme eleēmones en eleēthēsontai in subkolon .5 is die verskynsel paronomasia teenwoordig.

Só vind ons dus bo en behalwe die alliterende $p$ in die eerste vier subkola, 'n verdere alliterasie-assonansie-paronomasia skema binne die individuele subkola wat boonop 'n anaforiese oktaaf vorm. Vanaf vs 11 verderaan in die onmiddellike konteks vind ons nie meer aanduidinge van só 'n skema nie. Dit bevestig derhalwe die breuk tussen subkolon 8 en die daaropvolgende. Afgesien van die estetiese van hierdie klank- en woordspel, lewer dit dus ook'n bydrae om die "clusters" in die struktuur van die onmiddellike konteks af te merk.

Die negende makarisme (vs 11) neem sy eie unieke posisie binne die onmiddellike konteks in. Dit dien naamlik as die skarnier tussen die makarismereeks (subkola .1-8) en die volgende deel van die 
Bergrede (vss 13-16). Hierdie verbinding word formeel aangedui deur morfologiese elemente van beide te bevat, naamlik die lekseem makarioi wat na agter met die makarismereeks verbind, en die tweede persoon meervoud pronomen met sy gepaardgaande vervoegde vorm van eimi, wat vorentoe verbind ${ }^{16}$.

Die makarismereeks verdeel verder in twee kwatryne, naamlik .1.4 (aangedui met A) en .5-.8 (aangedui met B). Drie formele faktore is hiervoor 'n aanduiding: (a) As ons die lesing autoi in subkolon .7 aanvaar ${ }^{17}$, dan vind ons dat die somtotaal van die lekseme in beide kwatryne presies dieselfde is, naamlik ses en dertig. "The mathematical chance that this is purely accidental, is absolutely minimal ${ }^{\prime \prime}{ }^{18}$ (b) Die alliterasie-assonansie skema verskil opmerklik tussen die twee kwatryne. In subkola .1-.4 vind ons'n alliterende skema, terwyl daar by subkola $.5-.8$ 'n skema bestaan waar alliterasie om die beurt die assonansie afwissel (sien hierbo) - waarskynlik om stilistiese oorkarakterisering te vermy. (c) Die laaste subkolon van beide kwatryne (.4 en .8) bevat beide aan die einde van die matriks dieselfde geaksentueerde lekseem, naamlik dikaiosun $\bar{e}$ - 'n lekseem wat nie net in die makarismereeks en in die breër konteks ' $n$ belangrike rol speel nie, maar ook in die hele Matteusteologie.

In Matteus 5:3-10 is daar dus drie lekseme/lekseemkombinasie wat struktuurmerkend prominent funksioneer, naamlik die anaforiese makarioi, die lekseemkombinasie basileia tōn ouranōn wat aan die begin en einde van die oktaaf voorkom, en laastens die geaksentueerde diakaiosune wat aan die einde van die laaste subkolon van beide kwatryne aangetref word. ${ }^{19}$

By die ontleding van die dieptestruktuur sal aangetoon word dat die inhoud met bostaande struktuur korreleer. Maar eers is dit nodig om die makarismereeks teen die perspektief van die struktuur van sy wyere konteks te plaas.

\section{Die struktuur van die wyere konteks (Matt 4:23-9:35)}

Die makarismereeks vorm baie duidelik 'n element van 'n groter geheel wat tradisioneel as die Bergrede bekend staan (Mat. 4:257:27). die Bergrede maak op sy beurt weer deel uit van 'n groter geheel in die Matteusevangelie, naamlik Matteus 4:23-9:35. Uit die aard van die saak sal daar nie op al die sintaktiese, stilistiese en semantiese eienskappe van só 'n wye konteks ingegaan kan word nie. Alleen die relevante resultate word aangebied.

Behalwe vir 4:23 en 9:35 word die verskillende kola vanweë woord-ekonomiese oorwegings nie een vir een uitgeskryf of genommer nie. Ons werk slegs met konlongroepe (in die struktuuranalise met Romeinse syfers aangedui). Sommige van die eenhede wat as kolongroepe aangedui word, bestaan slegs uit een kolon $(4: 23 ; 4: 24$ 
en 9:35), maar beklee in die struktuur van die konteks dieselfde funksie as die ander kolongroepe. Ander kolongroepe bestaan weer uit kleiner kolongroeperinge, en dit word aangedui met die hoofletters A, B, C, ensovoorts. Teenoor elke kolongroep word 'n baie kort parafrase van die inhoud van die betrokke kolongroep aangebied. Die Bergrede (Matt 4:25-7:27) met die afsluitende formule kai egeneto hote etelessen ho lèsous tous logous toutous ... (Matt 7:28-29) vorm 'n komposisionele eenheid wat vir die doel van ons bespreking van Matteus 4:23-9:35 dieselfde funksie beklee as die ander kolongroepe. Dit word daarom met die Romeinse syfer III aangedui. Ter wille van verwysingsdoeleindes word die versnommers waaruit die verskillende kolongroepe bestaan, en soos dit in die Bybel aangebring is, aangetoon.

4:23 kai periēgen en holē tē Galilaia,

[didaskōn en tais sunagōgais autōn

Lai kērussōn to euangelion tēs basileias -kai therapeuōn pasan noson kai pasan

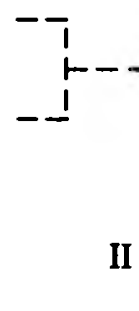

II

$4: 24$

Algemene aanduiding van Jesus

se genesende bediening.

4:25-

III $L_{-} \begin{aligned} & \text { 7:28 } \\ & \text { 7:28-29 }\end{aligned}$

Bergrede.

Afsluiting van diskoers met formule: kai egeneto hote etelesen ho Iésous tous logous toutous...

IV $\left[\begin{array}{cc}\text { A } & 8: 1-4 \\ -B & 8: 5-13 \\ \text { C } & 8: 14-17\end{array}\right.$

Genesing van die melaatse.

Genesing van die dienskneg van die hoofman.

Genesing van die skoonmoeder van Petrus, en die skare

A

$\mathbf{B}$

C

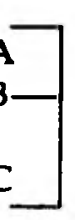

8:18-22 Navolgingskap: Niks moet in waarde hoër geag word as dissipelskap nie.
VI $\left[\begin{array}{l}\text { A } 8: 23-2 \\ \text { B } 8: 28-3 \\ \text { C } 9: 1-8\end{array}\right.$

Jesus maak die storm stil.

Genesing van die twee besetenes van Gadara.

Genesing van die verlamde man in Kapernaum. 


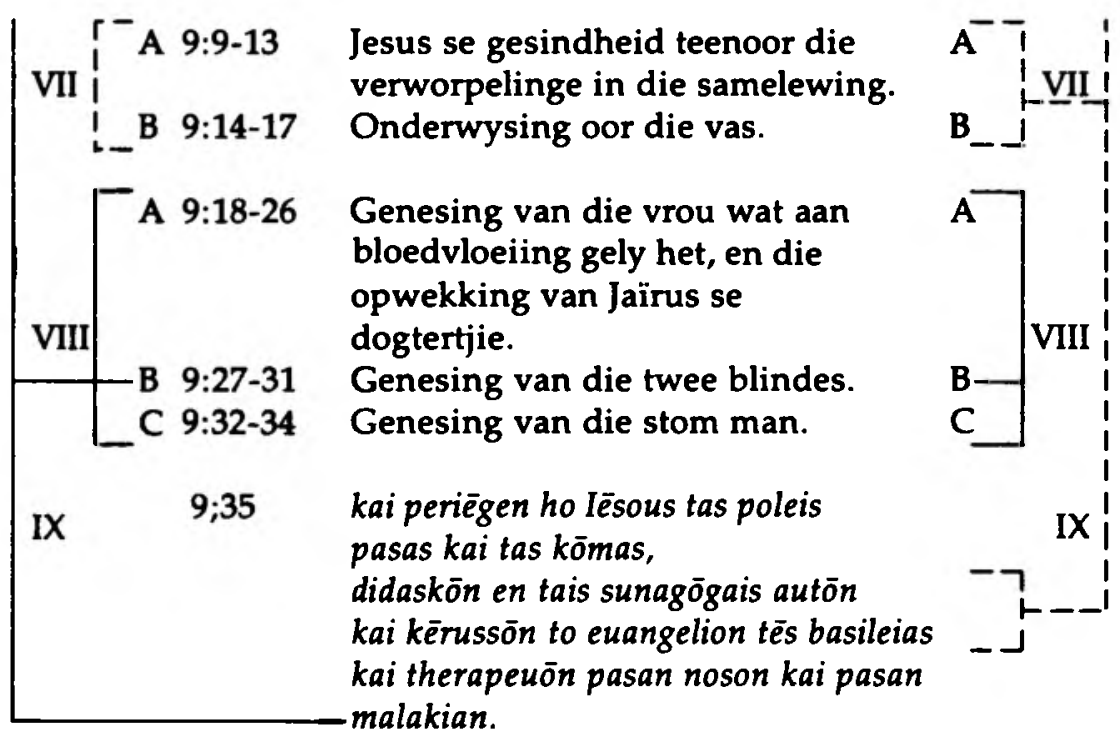

Matteus 4:23-9:35 vorm 'n ringskomposisionele eenheid wat met nagenoeg identiese bewoording begin en eindig (seksies I en IX) ${ }^{20} \mathrm{~A}$ B du Toit ${ }^{21}$ wys daarop dat die ringskomposisie hier nie as ' $n$ statiese argument gebruik word nie, maar dat die tipies van Matteus se komposisionele metode soos ' $n$ spiraal in 'n progressiewe sirkelbeweging funksioneer. Seksie I funksioneer soos 'n sleutel as die programmatiese inleiding vir dit wat gaan kom, en seksie IX as 'n opsomming van dit wat gesê is. Terselfdertyd dien seksie IX as die skarnier vir die gedeelte wat daarop volg en waarin die parallelisme tussen Jesus se bediening met dié van sy dissipels uitgebou word.

In die identiese inleiding en slot van seksies I en IX vind ons by wyse van die drie partisipale kommata (didaskōn ...; kērussōn ...; therapeuōn ...) verwysings na dit wat binne hierdie ringskomposionele eenheid gesê word. Die genesingsmotief word onmiddellik opgeneem deur in seksie II ' $n$ algemene beskrywing van Jesus se genesende bediening aan te bied. Dit word daarna weer opgeneem. In hoofstukke agt en nege word breedvoerig daaraan aandag gegee by wyse van individuele beskrywings naamlik in seksies IV, VI en VIII. In die Bergrede funksioneer die didaktiese motief dominant. Dit kom egter ook voor in hoofstukke agt en nege waar die.individuele beskrywings van Jesus se genesende bediening in vertellings van drie-drie gegroepeer word. Seksies IV en VI bestaan uit eenhede $A$, $B$ en $C^{22}$ So bestaan seksie VIII ook uit eenhede A, B en $C .^{23}$ In albei gevalle word die triologiese groeperinge deur vertellings oor onder- 
wysings van Jesus onderbreek (naamlik IV $A B C$ deur $V$ en VI ABC deur VII, waarna VIII ABC volg). Volgens J P Louw moet ons hierdie onderbrekings nie net as stilistiese onderbrekings opneem nie, maar as eggo van die onderrig in seksie III. Dit plaas die onderrig van die Bergrede sterk op die voorgrond. Die relasies van dié eenhede waarin die didaktiese motief domineer, word in die struktuuranalise aan die regterkant by wyse van gebroke verbindingslyne aangetoon, terwyl die relasies van die eenhede waarin die genesingsmotief domineer, aan die linkerkant by wyse van ononderbroke verbindingslyne aangetoon word.

Om saam te vat: Vanuit die analise van die oppervlaktestruktuur is aangetoon dat die makarismereeks in Matteus 5:3-10 'n kunstige komposisionele eenheid is met sy fokuspunte op die drie terme makarioi, basileia tōn ouranōn en dikaiosunē. Die makarismereeks verbind via vss 10-11 met die res van die Bergrede. Die Bergrede self as eenheid (wat as die exemplum classicum van die vroeg-Christelike didachē beskou kan word) maak op sy beurt deel uit van 'n wyere ringskomposisie (4:23-9:35). In hierdie wyere konteks word die didaktiese met die genesingsmotief afgewissel. In die lig van hierdie struktuur word dit glashelder dat die makarismereeks as die exordium van die didaktiese Bergrede funksioneer ${ }^{24}$ asook van die breër konteks waar die genesingsmotief dominant is (afgewissel met die didaktiese). Die posisie van die makarismereeks binne die struktuur van sy nouer konteks (4:25-7:29) en breër konteks (4:23-9:35) moet dus verstaan word in die lig van dié twee motiewe wat binne hierdie wyere struktuur domineer, naamlik die didaktiese en die genesingsmotief.

In die analise het ons egter opgemerk dat afgesien van bogenoemde twee motiewe daar nog ' $n$ derde in die ringskomposisionele raamwerk van die wyere struktuur voorkom, naamlik die kerugmatiese. Laasgenoemde, anders as die didaktiese en genesingsmotief, word nie in die oppervlaktestruktuur geartikuleer nie. As ons nou op grond van 'n dieptestruktuuranalise kan bewys dat die makarismereeks kerugmaties funksioneer, dan sal dit daarop dui dat die versweë kerugmatiese motief sy plek binne die makarismereeks kry.

\section{Die dieptestruktuur}

Die dieptestruktuur word ontleed deur die semantiese funksies van die lekseme, lekseemkombinasies en kola in die perikoop te bepaal en te omskryf. Die kategorie "gebruik" is op hierdie vlak van die ondersoek ter sake. Die tegniek wat E A Nida en C R Taber ${ }^{25}$ met die oog op ' $n$ dinamiese Bybelvertaling ontwerp het, word gevolg. Dit word gedoen met behulp van die universele semantiese kategorieë objekte, gebeure en abstrakte. Die tegniek om die relasies van lek- 
seme in hulle groepsinhoud binne die afsonderlike kola te bepaal, die sogenaamde konstituente-analise (I C-analise), word kolonsgewys met die dieptestruktuurontleding gekombineer. Die drie terme wat in die perikoop struktuurmerkend prominent funksioneer, naamlik makarioi, basileia tōn ouranōn en dikaiosunēe, vereis egter vereers ' $n$ nadere beligting.

\section{Die woordgroep makarios, -ia, -ion; makarizō/makariō; makarismos}

Die lekseem makarios, -ia, -ion en die stamverwante derivate (makari$z \bar{o} /$ makariō; makarismos) kom vyf en vyftig keer in agt en dertig perikope in die Nuwe Testament voor. In al hierdie gevalle dien dit as geluk-aankondiginge. Twee en vyftig keer het dit die semantiese funksie van psigologiese gebeure en kan daarom getipeer word as abstrak-gebeurewoorde. ${ }^{26}$ Dit druk naamlik 'n kwalitatiewe toestand uit, maar dui tog ook 'n proses aan. As ons die. "gebruike" in al twee en vyftig gevalle nagaan, dan merk ons dat, met die uitsondering van Handelinge 26:2 en Galate 4:15, dit na 'n religieuse heilsaankondiging van 'n soort blydskap of geluk verwys wat op een of ander wyse deelname aan die Christelike eskatologie impliseer. In Handelinge 26:2 en Galate 4:15 vind ons ' $n$ verwysing na 'n nie-religieuse tipe blydskap. Die laaste drie gevalle (1 Tim 1:11,6:15 en Tit 2:13) kan as ' $n$ "suiwer" abstrak getipeer word. Hulle "gebruike" verskil in dié opsig dat in eersgenoemde twee gevalle dit na 'n predikaatseienskap van God verwys en die ander na 'n predikaatseienskap van 'n onpersoonlike gawe van God. ${ }^{27}$

Die anaforiese makarioi in Matteus 5:3-10 hoort tot die eerste groepering. Dit is dus ' $n$ abstrak-gebeurewoord wat ' $n$ psigologiese proses van 'n geluk-aankondiging aandui en wat verwys na die blydskap wat die deelname aan die Christelike eskatologie (en die rykdom wat dit alles kan inhou) meebring.

\section{Dikaiosunē}

Wat die lekseem dikaiousune betref, het J $\mathrm{P}$ Louw ${ }^{28}$ 'n deurtastende ondersoek na die betekenis en gebruik daarvan in die Bergrede gedoen. Daarom is ' $n$ herhaling daarvan hier onnodig en maak ek hoofsaaklik van sy resultate gebruik. Die betekenis van dikaiosune in die Bergrede ${ }^{29}$ kan ook as ' $n$ abstrak-gebeurewoord getipeer word. Dit dui op die kwaliteit "korrektheid" wat terselfdertyd 'n handeling is waardeur dié kwaliteit blyk. In die Judaïca, net soos in die Bergrede, het dit 'n religieuse verwysing na 'n ... "virtue resulting in a way of life emphasizing correctness before God". ${ }^{30}$ Hierdie "lewenswyse" word in die Jodedom gerealiseer deur die vervulling 
van die Mosaiese wet. In die Bergrede is hierdie "lewenswyse" 'n beloning van God vir diegene wat die wet vervul, dit wil sê in korrektheid optree, mèt 'n gesindheid wat spruit uit 'n persoonlike verhouding met die hemelse Vader. Die Bergrede leer dat praktiese dade soos ... "alms, prayer and fasting ... praised by the scribes and Pharisees as righteousness itself, will only then become meaningful when being exercised before God alone because dikaiousunē means being right in the eyes of God". ${ }^{31}$

\section{$23 H \bar{e}$ basileia tōn ouranōn}

Die lekseemkombinasie hē basileia tōn ouranōn kom, as ons die tekskrities-twyfelagtige Johannes 3:5 buite rekening laat, slegs in die Matteusevangelie voor. Op drie ander plekke in die Matteusevangelie vind ons die alternatiewe uitdrukking wat by die Markus-, Lukasevangelie en elders voorkom naamlik he basileia tou theou. ${ }^{32}$ Basileia is ' $n$ gebeurewoord wat ' $n$ interpersoonlike aksie van "om te regeer" aandui. Dit kan in Afrikaans met "koningsheerskappy" weergegee word. Die tōn ouranōn moet in die lig van die kontemporēre laat Judaistiese gebruik as 'n substituut vir God opgeneem word. Lekseme soos byvoorbeeld mèmrā, škinnā y'qarē en šmayyã word dikwels onder andere in die Targums as substitute vir God gebruik wat naamlik verklaar moet word as ' $n$ eerbiedige vermyding van God se naam. ${ }^{33}$ Die gebruik van die meervoudsvorm tōn ouranōn is 'n Semitisme. Vanweë die verbinding van basileia met die subjektiewe genitiefkonstruksie tōn ouranōn is dit duidelik dat dit 'n koningsheerskappy is waarin God regeer. Dit is ' $n$ begrip wat by die kontemporêre Jodedom bekend was. "The basis of the Greek phrase was the corresponding Hebrew malkut Jahveh, which appears in this form only in rabbinical literature, and not in the Old Testament ... The basis of the rabbinical phrase is a proclamation in the Old testament, which appears with particular frequency in deuteroIsaiah: "Jahweh has become King". En verder: "For a Jew at the time of Jesus the short pharase basileia tou theou expressed everything good which he hoped for from God. ${ }^{134}$

$R$ Kassühlke het in ' $n$ ondersoek na die gebruike van die uitdrukking basileia tou theou in die Nuwe Testament bevind dat al die kontekste waarin die uitdrukking voorkom, in nege areas verdeel, naamlik:

(a) "God establishes his rule"

(b) "God destroys his enemies"

(c) "God eleminates sin, disease, suffering and death"

(d) "God completes his work (as creator and redeemer).

(e) "God calls men into fellowship with himself" 
(f) "God renews the world"

(g) "Men submit themselves to God's rule"

(h) "Men have complete fellowship with God"

(i) "Men live in the renewed world"

By 'n nadere ondersoek blyk dit egter dat area (b) en (c) by (a) ingesluit is, en (c) en (e) by (d). Area (e) kan ook by (f) ingesluit word, terwyl (g), (h) en (i) die menslike antwoord is op respektiewelik (a), (d) en (f). Areas (a) en (f) kan dus as dié twee fundamentele areas beskou word waarbinne die uitdrukking he basileia tou theou in die Nuwe Testament gebruik word. Hoewel Kassühlke dit nie vermeld nie, is area (f) op sy beurt weer 'n manifestasie van area (a). Ons werk dus vervolgens net met area (a). Hierdie "heerskappy van God" moet in die konteks van die evangelie verstaan word teen die agtergrond van die koms van die Messias wat in Jesus gerealiseer het. (Vergelyk die proklamasie van Johannes die Doper in Matteus 3:2 en dié van Jesus self in Matteus 4:17).

\section{4 ' $n$ Konstituente-analise van die perikoop met bespreking aan die hand van die kategorieë objekte, gebeure en abstrakte}

In die skema wat van die IC-analise by elke subkolon gebied word, word die lekseme in die subkolon semanties as $O$ (objek), $G$ (gebeure) of $A$ (abstrak) geklassifiseer. Dikwels gebeur dit egter dat byvoorbeeld 'n objek in die konteks as verwysend na byvoorbeeld 'n abstrak gebruik word. Sodanige gevalle sal in die bespreking aangedui word. ${ }^{35}$

Subkolon .1 Makarioi hoi ptōchoi tō pneumati, hoti autōn estin hē basileia tōn ouranōn

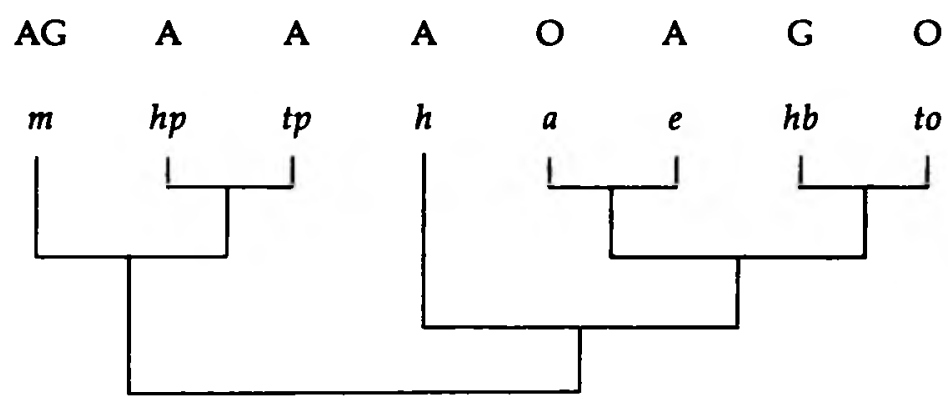

Dit is ' $n$ kolon wat net soos die ander in die reeks in twee dele uiteenval, naamlik in 'n matriks en 'n redegewende uitbreiding ingelei deur hoti. Die morfeem estin in die uitbreiding dui op 'n statiewe toestand en is daarom 'n abstrak. Die konstituente-verbinding van die abstrak estin met die objek autōn transformeer na: "hulle het 
deel aan". Die lekseemkombinasie hē basileia tōn ouranōn vorm in die dieptestruktuur die direkte voorwerp van die nominale frase "hulle het deel aan". In die semantiese bespreking van die uitdrukking $h \bar{e}$ basileia tōn ouranōn het ons dit hierbo getransformeer na: "Die heerskappy waarin God as koning regeer." B M Newman jr wys daarop dat die fokus in die perikoop geleë is ... "on the benefits of blessings shared by those persons who experience the rule of God in their lives. ${ }^{\prime 36}$ In die matriks word mense wat ptōchoi tō pneumati is, deur Jesus makarioi genoem. In die lig van my vroeëre bespreking hierbo kan ons makarioi se toepaslike noempotensie hier omskryf as 'n psigologiese abstrak-gebeurewoord wat as ' $n$ relignieuse heilsaankondiging met ' $n$ eskatologiese strekking vir mense gebruik word wat ' $n$ bepaalde gesindheid openbaar, te wete dan hier die gesindheid om ptōchos tō pneumati te wees. Die konstituente-verbinding van die abstrak hoi ptōchoi met die abstrak tó pneumati kan konkordant weergegee word met "mense wat arm in die gees is". Vele kommentatore is dit eens dat hierdie eerste makarisme (soos ons later sal sien, geld dit ook ander in die reeks) ' $n$ toespeling is op Jesaja $61: 1 \mathrm{ev}^{37}$ en dan in die besonder op die tweede hemistige van die eerste stige in vs 1 :

$$
\begin{aligned}
& \text { rūah วa donāy yhwh 'âlāy } \\
& \text { yacan māšah yhwh 'otī lebaśśệr ca nāwìm }
\end{aligned}
$$

Die ${ }^{c a} n \bar{a} w \bar{m} m$ wat met die ptōchoi tō pneumati geidentifiseer word, is die toespeling op die kontemporêre ${ }^{c a} a m h \bar{a}^{2} \bar{a} r e s$ Laasgenoemde was in die oë van die Fariseërs en die skrifgeleerdes die veragtes. Hulle is daarom as buite die verbond gereken. ${ }^{38}$ Die ${ }^{c a} n \bar{a} w \vec{\imath} m$ wat as die sorglose en die reglose by Yahweh beskerming soek teen hulle vyande en ook die privilege geniet om by Hom toevlug en redding te ontvang, word deur Trito-Jesaja gebruik vir die volk in ballingskap wat smag na die herstel van die gemeenskap met Yahweh. Dit word geherinterpreteer asof dit op die kontemporêre ${ }^{c a} a m h \bar{a}^{2} \bar{a} r e s ̦$ van toepassing sou wees. Soos dit aan die einde van die bespreking oor die makarismereeks sal blyk, maar ook vanuit die konteks in die Bergrede as geheel, is daar 'n duidelike ooreenstemming tussen die toestand wat onder die 'am $h \bar{a}^{2} a \bar{r}$ reș heers en dié wat in die makarismereeks beskryf word. In die lig van die midraš wat ons dus hier aantref, kan ons wat die gebruik van die uitdrukking hoi ptōchoi tō pneumati betref, saam met $\mathrm{G}$ Eichholz ${ }^{39}$ die tō pneumati as 'n tipe dativus relationis beskou. "Geist meint hier nicht Verstand oder Vernunft, sondern dass Innere des Menschen, zein Herz." ${ }^{\prime \prime 0}$ tō pneumati wat suiwer leksikalies gesien, op ' $n$ psigologiese kapasiteit dui en daarom ' $n$ absstrak is (vergelyk die skema hierbo), vorm saam met die abstrak hoi ptōchoi 'n semantiese eenheid. Dit is dus wat sy gebruik hier betref, 'n objek. Ons kan derhalwe "arm in die gees" 
soos volg verstaan: "Menschen sind gemeint, deren äussere Lage, sie dahin treibt, dass sie alles von Gott erwarten. ${ }^{\prime \prime 1}$ Die makarisme moet dus nie só opgeneem word as sou almal wat lid is van 'n bepaalde sosiale laag - in dié geval die ' $a m$ hääres - die ontvangers wees van die eskatologiese heil wat hier aangekondig word nie. Dit is die gesindheid wat kenmerkend van die ${ }^{c a} a m$ h $\bar{a}^{2} \bar{a} r e s ̦$ is, wat hier eksemplaries geïnterpreteer word.

Om saam te vat: lemand wat ptōchos tō pneumati is, het niks om uit homself vir sy saligheid by te dra nie. Soos 'n geestelike bedelaar staan hy voor God, volkome afhanklik van wat God in sy goedheid gee. En God skenk in Jesus Christus hom deelname aan die basileia tōn ouranōn. Vanweë Jesaja 61:1 wat in hierdie subkolon 'n belangrike rol speel, bring die gebruik van die lekseme en frases in die subkolon (soos ook in al die ander subkola in die reeks) die Messiaanse motief sterk na vore.

Subkolon .2 makarioi hoi penthountes, hoti autoi paraklēthēsontai

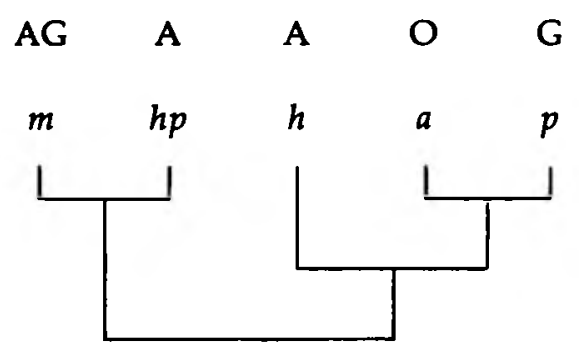

Die passiewe konstruksie van die redegewende uitbreiding kan transformeer na "aliquis sal hulle troos." Die subjek aliquis slaan op God. 'n Eerbiedige vermyding van God se naam word dikwels by die Jode deur middel van 'n passiewe konstruksie bewerkstellig. Só ' $n$ konstruksie is deel van Matteus se Semities-Griekse skryfstyl. ${ }^{12}$

Hierdie makarisme is waarskynlik 'n toespeling op die l'nahẹm kol zubelìm in Jes 61:2. Die Septuaginta vertaal hierdie uitdrukking met parakalesai pantas tous penthountas. Net soos in die eerste makarisme, sowel as ook in ander in die reeks, vind ons in hierdie subkolon 'n tipe midraš op Jesaja 61:2. In die aanbod van troos vir hulle wat treur, kondig Jesus Homself aan as die Messias wat in Jes 61 beloof is. Want al het Jesaja 61 tyds-histories betrekking op die volk in ballingskap, het die Joodse tradisie in die vertroosting van Israel 'n aanduiding begin sien van die verwagting van die Messias. In Lukas 2:25 en 26 vind ons onder andere spore van só ' $n$ tradisie. En só het die woord $m^{2}$ nahẹm inderdaad ' $n$ Joodse Messiasnaam geword. ${ }^{43}$ Tröstung der Trauernden ist messianisches Handeln. ${ }^{44}$ Die hoi penthountes wat semanties ' $n$ objek-abstrak is, dui op 'n psigologiese 
gesteldheid. Net soos in die geval van die 'aẹlim wat in Jesaja 61 'n verdere toeligting is op die cañwim, is die penthountes 'n toeligting op die hoi ptōchoi tō pneumati.

Wat deur hierdie makarisme geimpliseer word, is afgesien van die Messiaanse handeling en die toespeling op die toestand wat onder die 'am $h \bar{a}^{3} a \bar{r}$ res heers, nie vanuit die konteks duidelik nie. "Most likely the idea is simply intended to contrast the mourning of the present age with the 'comfort' of the coming age; at least this is highly probable in light of its connection with the words from Isaiah". ${ }^{45}$

Subkolon .3 makarioi hoi praeis hoti autoi klēronomèsousin tēn gēn

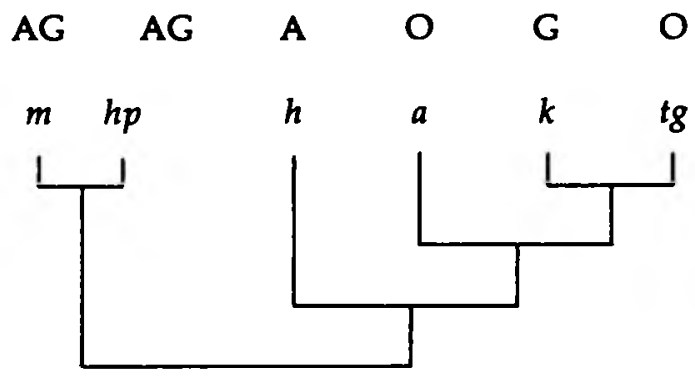

Dit is ' $n$ subkolon waarvan die matriks in die dieptestruktuur na twee kernsinne teruggaan, en die redegewende uitbreiding na een, naamlik:

matriks: die ootmoediges is gelukkig

hulle is ootmoedig

uitbreiding: hulle beërwe die land

Die praeis is ' $n$ abstrak-gebeurewoord wat ons iets vertel van ' $n$ bepaalde gedrag en dit gaan inhoudelik terug na dit waarna die ptōchoi tō pneumati van die eerste makarisme verwys het. Volgens Klaus $\mathrm{Koch}^{46}$ is hierdie derde makarisme ' $\mathrm{n}$ implisiete korrigering van die laaste stige in Jes 61:6 (ḥẹl gōyim to kệu ubikebōdām tityammārū), en 'n direkte toespeling op die eerst hemistige van Psalm 37:11

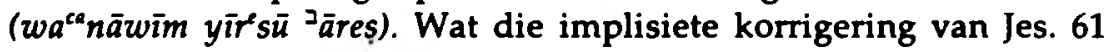
betref, reken Koch dat die gedagte van die oorheersing van Israel oor die volkere en die genieting van hulle rykdom in die makarismereeks vervang word met dié van die toekomstige ongebroke gemeenskap met God. Dat die derde makarisme ten minste teen die agtergrond van Psalm 37:11 verstaan moet word, is die oortuiging van al die geraadpleegde kommentatore. Die ooreenkoms word ook opvallender as daarop gelet word dat die betrokke hemistige in Psalm 37:11 in die Septuaginta vertaal word met praeis klēronomésou$\sin g^{\bar{e}}$. Uit die verwysings in $S t r-B^{47}$ kan gesien word dat die metafoor "die land beërwe" in die Jodedom 'n element geword het van Israel se heilsverwagting, naamlik dat die volk eenmaal ongestoord 
sal mag woon in die beloofde land as erfenis. Die verwagting van hierdie erfenis was met ander woorde vir Israel verbonde aan die aardse beloofde land, Israel se nasionale bestaan. Maar in die laatJodedom, en meer nog in die Apokaliptiek, ${ }^{40}$ is hierdie verwagting van die aardse losgemaak en aan die aiōn mellōn verbind.

As ' $n$ verdere toeligting op die eerste twee makarismes vind ons in die lig van die bestaande Joodse tradisie in die derde makarisme ' $n$ Messiaanse heilsaankondiging van 'n eskatologiese blydskap vir diegene wat hulle eie wil gebuig het en met ' $n$ bepaalde gesindheid voor God staan, naamlik as mense wat geen aansprake voor God het nie. Sulkes sal die hemelse vaderland beërwe.

Subkolon .4 makarioi hoi peinōntes kai dipsōntes tēn dikaiosunēn, hoti autoi chortasthēsontai

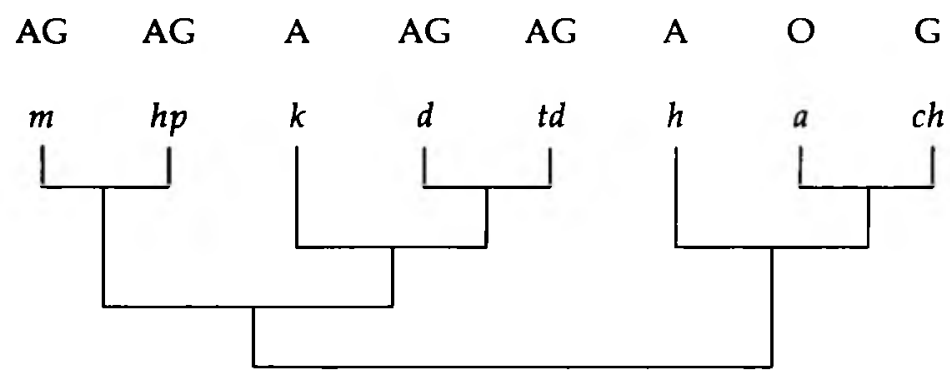

Die dieptestruktuur van hierdie subkolon is, soos die konstituenteanalise reeds aandui, gekompliseerd. Die matriks gaan na vier kernsinne terug, naamlik:

hulle is honger na wat reg is

hulle is dors na wat reg is

die wat honger na wat reg is, is gelukkig

die wat dors na wat reg is, is gelukkig

Hierdie makarisme vat die kern saam van die waarom dit in die Bergrede gaan, naamlik om die doen van dikaiosune. Want soos reeds daarop gewys is, moet die lekseem dikaiosune wyer gesien word in die lig van sy gebruik binne die Jodedom, en wat Jesus in teenstelling daarmee van sy volgelinge verwag het. Jesus verlang naamlik van hulle 'n diakaiosunēn pleion. (Vergelyk Matt 5:20 - "Ek sê vir julle: As julle getrouheid aan die wet nie meer inhou as dié van die skrifgeleerdes en die Farisers nie, sal julle nooit in die koninkryk van die hemel ingaan nie.")

"Honger" en "dors" druk 'n toestand uit wat op 'n psigologiese proses dui. dit is daarom abstrak-gebeurewoorde wat gebruik word as beeld van die verlange na God (vergelyk Jes 55:1; Ps 42:2; Barug 2:18; Joh 4:13 ev; 7:37; Openb 21:6; 22:17).$^{49}$ Letterlik opgeneem laat 
dit egter ook 'n ander aspek van die 'am $h \bar{a}^{-} a \bar{r} r s ̦$ sien. Soos honger en dors ' $n$ elementêre nood van die ${ }^{\text {ca }}$ näwim is (Jes 61), so is hulle "versadiging" die Messiaanse vervulling van hulle eskatologiese hoop. "Again, in keeping with Semitic language usage, which has influenced the Greek Style of Matthew, the passive construction ('shall te satisfied') should be transformed into an active construction with God as the subject: 'God will satisfy them'." 50 "Das 'Gesattigtwerden' meint Gottes eschatologische Tat, die eins ist met dem kommen seines Reiches". ${ }^{51}$

Die term "beeld" hierbo beklemtoon die belangrikheid van die gebruik van lekseme en frases in die makarismereeks. Hierdie gebruik geskied telkens teen die agtergrond van die Ou Testament en die Judaïca. Dit korreleer ook met die grammatiese Grieks-Semitiese skryfstyl in die evangelie.

Subkolon .5 makarioi hoi eleēmones, hoti autoi eleēthēsontai

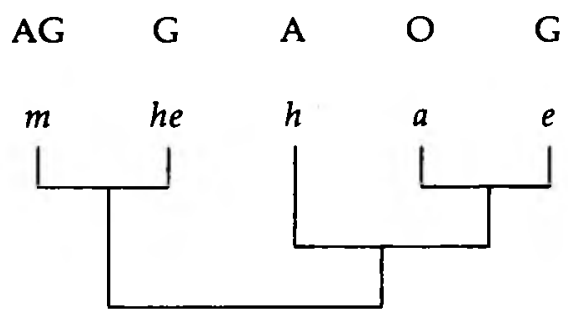

Die vyfde makarisme gaan op 'n redelike ongekompliseerde dieptestruktuur terug. Wat die gebruik van die lekseem eleein betref, kan opgemerk word dat dit vir die Jodedom onder andere die gee van aalmoese ingesluit het, en dat "barmhartigheid" as 'n groot deug beskou is. Dit was egter verbode om aan die 'am hāa âreș barmhartigheid te bewys. ${ }^{52}$ "Für Jesus ist nach Matthäus demgegenüber das Tun der Barmherzigkeit der Wille Gottes, der über alle gesetzliche Vorschrift und alles kultische Tun hinausreicht ${ }^{\prime 53}$ (vergelyk Matt 9:13 en 12:7). In aansluiting by die strekking van die res van die makarismes in hierdie reeks, vind ons in die vyfde makarisme ' $n$ aanklag teen die eksklusiewe partikularisme van die rabbyne. Nielsen is daarom korrek om in die daad van barmhartigheid "een uiting van gerechtigheid" te sien. ${ }^{54}$

Jesaja 61:2 speel onmiskenbaar' $n$ rol in die vyfde makarisme - met 'n Messiaanse heilsimplikasie. In die herhaling van die verwante morfeem in die matriks en in die redegewende uitbreiding (eleemones en eleêthēsontai), vind ons die gedagte van voorwaarde (nie in die sin van "verdienste" nie) $)^{55}$ en vergelding In die gebruik van die lekseme rāsōn ("welbehae") en nāgām ("vergelding") respektiewelik in die eerste en tweede hemistige van Jesaja 61:2, word eersge- 
noemde aan die ${ }^{c a}$ nāwìm toegesê. Die Messiaanse heilsimplikasie, en die teendeel van "vergelding", spreek dus in die vyfde makarisme vanself. Dit is inderdaad moontlik om in die passiewe futurum van die werkwoord eleêthésontai (soos wat dit in sekere opsigte ook vir die passiewe konstruksies van die tweede, vierde en sewende makarismes geld) 'n daad van God se "barmhartigheid" te sien wat betrekking het op die laaste oordeel. ${ }^{56}$

"The meaning of this verse then is that whoever shows mercy towards others will receive mercy from God." ${ }^{57}$

Subkolon .6 makarioi hoi katharoi tē kardia, hoti autoi ton theon opsontai

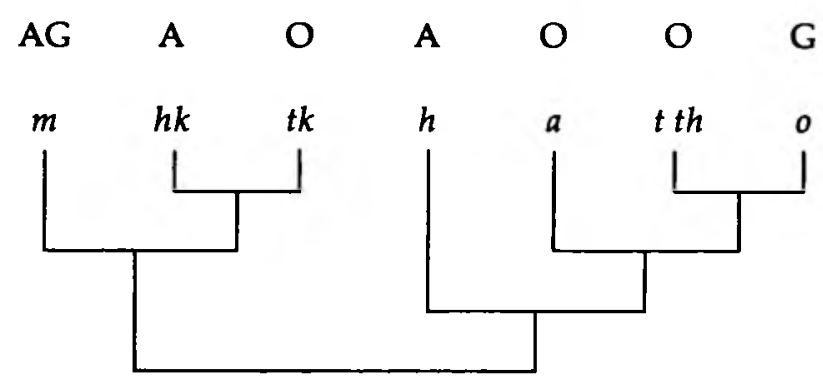

Die lekseem katharoi wat 'n abstrak vorm ten opsigte van $t \bar{e}$ kardia (laasgenoemde is semanties gesien, ' $n$ objek), dui op 'n bepaalde gedrag. Kardia is dus wat sy gebruik hier betref 'n abstrak. Soos deurgaans in hierdie makarismereeks, staan die gebruik van die lekseme en frases in die sesde makarisme inderdaad dus meer op die voorgrond as die lekskilasie betekenisse daarvan. Die algemene Bybelse gebruik van die woord "hart" dui die middelpunt van die persoonlikheid, die sentrum van die menslike wese aan. ${ }^{58}$ "Herz (kardia) ist parallel mit dem anthropoligisch gebrauchten Geist (pneuma) in 5:3, und kardia setzt das hebraīsche Aguivalent leb voraus. ${ }^{1159}$ Dit is verder opvallend dat die Targum op die Psalms die uitdrukking bar lẹbāb ("suiwer van gedagte") in Psalm 24:4 weergee met $b^{c}$ rìr racyōnā ("suiwer/rein van gedagte") en die bārē lẹbab van Psalm, 73:1 met $b^{c} r \bar{r}$ lẹbāb.$^{60}$ Verskeie navorsers sien in hierdie sesde makarisme ' $n$ implisiete aanknoping by Psalm 24:4-6 (LXX, hfst 23). ${ }^{61}$ Daar bestaan ook ' $n$ verdere parallel tussen die ton theon opsontai van die redegewende uitbreiding met die zêtountōn to prosōpon tou theou van Psalm 24:6. die uitdrukking "om God te sien" word naamlik in die Rabbinica onder andere weergegee met ra ${ }^{2} a w a t p^{e} n \bar{e}$ $\bar{s}^{z} k \bar{n} \bar{a}$ ("die aanskoue van die aangesig van die $\bar{s}^{2} k \bar{n} \bar{a}^{\prime \prime}$ ) wat in 'n oordragtelike sin met die Ou-Testamentiese uitdrukkinge "voor God verskyn", "voor God te staan" vergelyk kan word. ${ }^{62}$ 
Hierdie makarisme moet ook as 'n aanklag teen die rabbynse eksklusiwisme opgeneem word. Die "reinheid van hart" wat hier ter sprake is, gebruik Jesus hier as teenstelling met die "äusserlich kultischen Reinheit" waarvan die rabbynse Jodedom soveel waarde geheg het, ${ }^{63}$ maar waarby die ' $a m h \bar{a}^{2} \bar{a} r e s$ uitgesluit was. ${ }^{64}$ Dit word verbind met die redegewende uitbreiding hoti autoi ton theon opsontai - 'n uitdrukking wat in die Rabbinica op alle mense sonder onderskeid betrekking het, maar wat slegs vir die wat volgens die fariseïstiese reinheidswette lewe, Messiaanse eskatologiese heilsimplikasies inhou. ${ }^{65}$ In Psalm 24 word "geregtigheid", "seën" en "heil" vir die "reines van hart" deur Yahweh die Koning geskenk. In die sesde makarisme word Psalm 24 geherinterpreteer en is dit Jesus, die Messias-Koning wat die gewer is.

Ons vind dus in hierdie makarisme 'n Messiaanse heilsaankondiging vir diegene wie se leefswyse rein is van onsuiwerheid, maar ook van dubbelhartigheid. "The ultimate goal of the religious life is that of experiencing the Divine, and so those who are undivided in their hearts are quaranteed the vision of God. ${ }^{66}$

Subkolon 7 makarioi hoi eirēnopoioi, hoti autoi huioi theou klēthēsontai

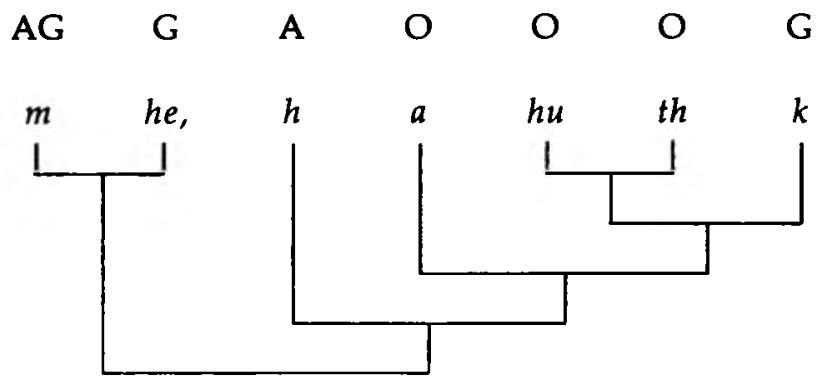

Die dieptestruktuur van die sewende makarisme is net soos die sesde ongekompliseerd. Dit gaan terug na drie kernsinne waarvan twee die matriks in die bobou vorm en een die redegewende uitbreiding. Die passiewe konstruksie waarin laasgenoemde gegiet is, kan net soos die ander in die reeks, transformeer na 'n aktiewe konstruksie waarin God die handelende subjek is, naamlik: "God sal hulle kinders van God noem". Afgesien van die passiewe konstruksie, is die gebruik van huioi ook Semities van aard. Net soos die Hebreeuse/Aramese $b^{e} n \bar{e}$ word "seuns" generies vir "kinders" gebruik.

Die lekseem eirēnopoioi is, soos ons reeds by die bespreking van die oppervlaktestruktuur vermeld het, ' $n$ hapax legomenon in Bybelse Grieks wat deur die evangelis waarskynlik ter wille van assonansie hier gebruik is. Die leksikaliese betekenis daarvan blyk ongekompliseerd, en dit word in Afrikaans gewoonlik vertaal met "vredema- 
kers". Dit is weer eens die gebruik van die lekseem (maar ook van die ander frases in die makarisme) wat ons aandag verdien, maar wat ons in hierdie geval egter nie tot klinkklare konklusies lei nie.

Dit waarna eirēnopoioi verwys, was in die kontemporêre Jodedom goed bekend. Dit is weergegee met die Aramese ${ }^{c a} \bar{s}^{j} \bar{a} \bar{s}^{e} l a \bar{a} m \bar{a} .{ }^{67}$ Hieronder is sowel ' $n$ "versoening" tussen mens en God, as tussen mens en mens verstaan. Só ' $n$ vredemakery is deur die rabbyne baie hoog geag. Nêrens vind ons egter in die Rabbinica 'n tradisie waar die ${ }^{c a} \mathbf{s}^{a} a$ $\varsigma^{c}$ lāmā met die beloftes van om "seuns van God genoem te word" verbind is nie. Dit is egter 'n vraag of die huioi theou in die sin van die Psalms van Salomo (vergelyk onder andere hoofstuk 2:13;2:18; 9:4; 9:7; 18:13; asook 2 Makk 7:34 ev; Henog 101:1) verstaan moet word as die "vromes", of as 'n ekwiwalent vir die sesde makarisme se ton theon opsontai. Laasgenoemde moet eskatologies as "Engelgleichheit" opgeneem word ${ }^{68}$ Dit lyk of daar meriete in Grundmann se standpunt is, naamlik dat ons die sewende makarisme teen die agtergrond onder andere 1 Kronieke 22:9-10 moet verstaan. Daar vind ons dat daar in ' $n$ belofte van God aan Dawid ' $n$ verbinding gemaak word tussen Salomo se "Friedensregiment" en sy "Gottessohnschaft". "Diese Verbinding steht der altorientalischen Hoffnung auf ein grosses Friedensreich der Menschheit nahe, dessen Herrscher Gottes Sohn ist; aus ihr lebt seit Alexander dem Grossen jener hellenistische Herrschergedanke, der die Gottesohnschaft des Herrschers und sein Friendenstiften miteinander verbindet. Auf diesem Hintergrund steht die Seligpreisung der Friedenstifter. Idem Jesus die armen Galiläas zum Friendenstiften aufruft, wird deutlich, dass auch die kleinste versöhnende Tat zwischen Menschen, die an einer unscheinbaren Stelle möglich wird, Gottes grosse Verheissung in sich trägt". In hierdie opsig bevat ook hierdie makarisme Messiaanse eskatologiese heilsimplikasies vir mense wie se lewens van 'n dikaisosunēn pleion getuig. "Friedenstiftung und Sohnschaft ... sind Werk und Würde des messias und Seliggepriesenen wirken mit am Werk des Messias und teilen darum seine Würde." ${ }^{\prime 69}$

Hierdie makarisme is ook ' $n$ aanklag teen die dubbelhartigheid van die rabbyne. Hulle wat só 'n groot waarde aan ${ }^{c a}$ śa ấ šâmā heg, se lewe getuig van 'n ewe groot tweespalt tussen denke en dade. Hoewel Klaus $\mathrm{Koch}^{70}$ se "traditionsgeschichtliche" opmerking dat ons in die sewende makarisme 'n toespeling het op die eerste stige van

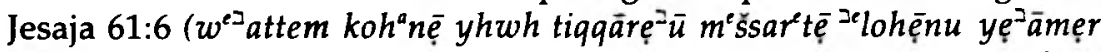
lāken) myns insiens nie bo alle twyfel kan bewys word nie, sit daar tog meriete in. Dit is moontlik dat die algemene strekking van Jesaja 61:1 e v (waar die lekseem ș $s^{e} \bar{a} q \bar{a}$ net soos in die geval van dikaiosun $\bar{e}$ in die makarismereeks, ' $n$ sleutelposisie beklee), en die Messiaanse midraš daarop in die Jodedom en die Nuwe Testament, 'n aanduiding is dat dieselfde klanke as dié van Jesaja 61:1 e $\mathrm{v}$ in die geheel 
van die makarismereeks weerklink. Verder kan daar 'n element van waarheid wees in die standpunt van Julius Schniewind wat van mening is dat Jesaja 52:7 in hierdie makarisme weerklank vind. Schniewind wys daarop dat die woorde van Jesaja 52:7 ("die vredebode wat vrede laat hoor") in die tyd van Jesus op die Messias van toepassing gemaak is. Volgens hom vind ons in die sewende makarisme weerklank van hierdie Ou-Testamentiese teksvers, en is Jesus die "Vredevors" self in woord en daad teenwoordig. ${ }^{71}$

Hierdie standpunt kan egter nie genoegsaam beredeneerd bewys word nie. In die lig van dit alles wat ons oor hierdie makarisme opgemerk het, wil ek dus voorkeur gee aan W Grundmann se standpunt met die oortuiging dat dit die beste met die algemene strekking van die reeks korreleer.

Subkolon .8 makarioi hoi dediögmenoi heneken dikaiosunē, hoti autōn estin hē basileia tōn ouranōn

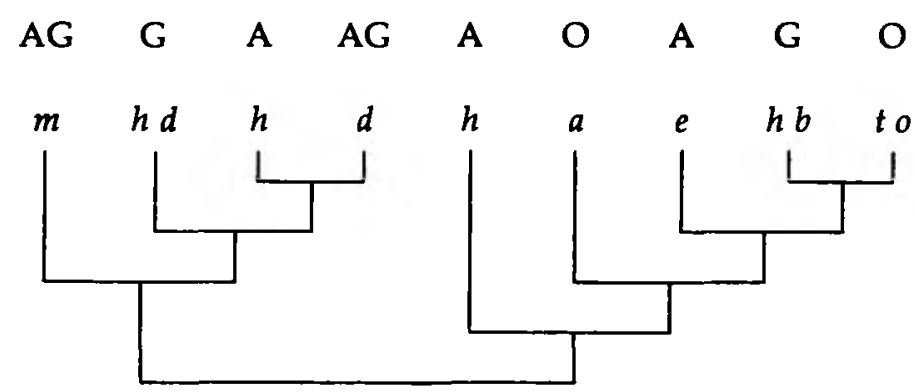

Omdat die redegewende uitbreiding die presiese herhaling is van dié van subkolon .1, en derhalwe reeds bespreek is, bepaal ons ons slegs by die matriks met sy drietal kernsinne. Daar is die psigologiese gebeurewoord makarioi, die passiewe perfektum partisipium van die interpersoonlike gebeurewoord dediōgmenoi, en laastens dikaiousunē wat net soos makarioi, reeds bespreek is. Dit is nie uit die konteks aanwysbaar wie as die handelende subjek by dediogmenoi opgeneem moet word nie. Daar is geen rede om soos Klaus Koch te vermoed dat hierdie makarisme in die loop van die tyd vanweë die druk van gemeentevervolginge tot die reeks toegevoeg is nie $^{71}$. Ook nie om soos J Schniewind ${ }^{73}$ en S P J J v Rensburg ${ }^{74}$ te meen dat Jesus sy eie dood en lyding met hierdie makarisme in die oog gehad het nie. Dit moet myns insiens eerder omvattend teen die agtergrond van die kontemporêre Jodedom verstaan word wat ook die vervolging van die dikaioi ken. "Jesus spricht ihnen als Gottes Geschenk das Himmelreich zu, wie er es den Armen am Anfang zugesprochen hatte. Damit nimmt er auf, was auch das Judentum wusste: 'Immer sucht Gott den Verfolgten' Lev. Rabba 27(123 c) $)^{\prime \prime 75}$. Hierdie agtste en laaste makarisme in die reeks dui op 'n verdere aspek van die ptōchoi 
tō pneumati, die penthountes, die praeis, ensovoorts. Die Messiaanse vervullingsmotief is met ander woorde net so sterk in hierdie makarisme teenwoordig as in al die ander.

\section{Gevolgtrekking}

31 Op die vraag of daar 'n differensiasie tussen die inhoude van die twee baie goed afgegrensde kwatryne in die reeks bestaan ${ }^{76}$ en of daar inhoudelike redes is vir die volgorde van posisie van die verskillende makarismes tot mekaar in die reeks, ${ }^{7}$ moet daar op grond van ons ondersoek negatief geantwoord word. Die oppervlaktestruktuur met sy anaforiese oktaaf en twee kwatryne is alleen funksioneel vir die aksentuering van die drie sleutelterme, makarioi, basileia tōn ouranōn en dikaiousunē. "Das ist in der zweiten Strophe nicht anders als in der ersten ... ${ }^{78 \prime \prime}$

32 Dit het geblyk dat die algemene strekking van die gebruik van die lekseme en frases hulle reliëf teen die agtergrond van die gebruik van die drie sleutelterme verkry. Dwarsdeur het dit dan geblyk dat ons hierdie algemene strekking moet verstaan teen die agtergrond van die kontemporêre Jodedom. Dit geld die toestand en gesindheid wat onder en ten opsigte van 'n bepaalde sosiale laag daarvan geheers het, naamlik die ' $a m h \vec{a}^{\supset} \bar{a} r e s ̧$. Ons het gesien dat dit wat in die eerste makerisme uitgespreek is, telkens in die ander makarismes met nuwe uitsprake verder tot 'n groter eenheid uitgebou is. In al die gevalle dui die gebruik van die drie sleutelterme (net soos die ander lekseme en frases in die reeks), in hulle tradisie-interpretasie teen die agtergrond van veral Jesaja 61, onmiskenbaar op 'n Messiaanse heilsgerigte, eskatologiese strekking. Maar dan 'n eskatologiese strekking wat op grond van veral die gebruik van die dikaiousune (en op grond van die "kwaliteite" van die "saliggesprokenes" wat telkens ' $n$ bepaalde optrede veronderstel) etiese implikasies bevat. Dit gaan in die makarismereeks om euangelion, om kerugma, om die aanbod deur die Messias self dat die beloofde basileia tōn ouranōn daar is. Die makarioi-uitsprake is in feite niks anders nie as die proklamasie van die aangebreekte eskatologiese basileia tōn oura$n \bar{n}$. En hierdie heilsaankondiging van ' $n$ eskatologiese blydskap geld vir mense met 'n gesindheid-plus-optrede ten opsigte waarvan teen die rabbynse Jodedom gepolemiseer word. Want in die makarismereeks word mense op 'n paradoksale wyse gelukkig geprys. Ernst von Dobschütz ${ }^{79}$ het tereg opgemerk dat die wese van die Christendom 'n religieuse paradoks vorm waar die heilige God Hom wend tot die sondige en verlore mens om hom te red. Daarom is die kerugmatiese en didaktiese motief waarna ons by die bespreking van die wyere konteks verwys het, in die makarismereeks ineen verstrengel. ${ }^{80}$ 
Deur nie alleen te let op die "betekenis" van woorde nie, maar ook op die "gebruik", het ons vasgestel dat die Joods-eskatologiese Messias-heil in die makarismereeks funksioneer. Dit gee aan dié etiesdidaktiese passasie 'n kerugmatiese dimensie sodat didaktiek en kerugma geïntegreer word. Die makarismereeks is dan juis die posisie binne die struktuur van sy wyere konteks waar die versweë kerugmatiese motief waarna ek vroeër verwys het, sy plek kry.

33 Dit het aanmerklike konsekwensies vir die interpretasie van die wyere konteks: Die makarismereeks is die exordium van die hele Bergrede. As sodanig verleen sy kerugmatiese kwaliteit (wat in die didaktiese element vervat is) ook kerugmatiese gehalte aan die res van die didaktiek in die Bergrede. En omdat die didaktiese passasies in die wyere konteks (waarvan die Bergrede die eerste sodanige gedeelte is) reëlmatig met die triologiese wonderverhale (veral genesings) alterneer, moet hierdie didaktiese passasies ook kerugmaties bepaald wees op grond van die inleidingsdidaktiek in die Bergrede. Dit geld daarom ook vir die triologiese wonderverhale wat reëlmatig daarmee alterneer. Die posisionele aspek van die makarismereeks korreleer dus ragfyn met sy inhoudelike funksie.

34 Die inhoud van taalgebruik word dus mede bepaal deur die kategorie "gebruik". Daarom speel diakroniese oorwegings ook 'n rol. Maar dit is altyd weer deur die sinkronies-immanente sintakties- stilisties- semantiese analise gekontroleer. Laasgenoemde is die beginpunt vir sinvolle eksegese.

\section{Verwysings}

1. Vgl o a R Wells, "Meaning and use", in S Saporta (ed), Psycholinguistics, New York 1961, 269-283; J W Oller jr, "On the relation between syntax and pragmatics", in Linguistics 83 (1972), 43-55; E A Nida, Exploring semantic structures, American Bible society 1972, 14 e v; J P Louw Semantiek van Nuwe Testamentiese Grieks, Pretoria 1876, 56-61; W de Pater, "Theologische linguistiek: situering en bibliografie," in $T$ Th 18 (1978), $242 \mathrm{v}$.

2. Aangehaal deur $\mathrm{R}$ Wells, $a$ w 272; $278 \mathrm{ev}$.

3. Vgl J Barr, Old and New in interpretation. A Study of the two testaments, Londen $1866,152 \mathrm{e} \mathrm{v}$.

4. W S Vorster, 'n Ou Boek in 'n nuwe wêreld. Gedagtes rondom die interpretasie van die Nuwe Testament, Unisa: Pretoria 1977, 10 v.; 23. Dit kan wees dat ek Vorster verkeerd verkeerd verstaan. Hy word egter onteenseglik deur baie verstaan as iemand wat die historiese kritiek op dieselfde vlak plaas as o a die Zeitgeschichte. (vergelyk sy "Some remarks on contemporary New Testament scholorship. Methodology and the study of the New Testament", in TE 10/2 en 3/1977, 33 ev.) Indien dit wel só is, dan degradeer Vorster die resultate van die historiese kritiek tot "voorkennis" wat deel uitmaak van die eksegeet se kompetensie.

5. W Richter, Exegese als Literaturwissenschaft. Entwurf einer altestamentlichen Literaturtheorie und Methodologie, Göttingen 1971, 189.

6. Die frustrasie is egter dat baie van hierdie histories-kritiese resultate, hoofsaaklik vanweë die gebrek aan vollediger "Einleitungs"-inligting, spekulatief bly.

7. W Richter, a w; G Fohrer cs, Exegese des Alten Testaments. Einführung in die Metho- 
dik, Heidelberg 1976'; J A Loader, Aspekte van menslike mag in die Ou Testament, diss. Groningen 1975; sien ook sy "Gedagtes oor gekontroleerde eksegese", in HTS jrg 34 (afl 1 en 2).

8. Dit wil vir my lyk asof W S Vorster, ' $n \mathrm{O}$ u Boek in 'n nuwe wêreld, $9 \mathrm{v}$, gelyk gegee moet word in sy kritiek op hierdie punt teen Richter, Barth en Steck e a. Dié kritiek sal in 'n nog groter mate geld vir die eksegetiese werkwyse van Loader. Laasgenoemde plaas die inhoudsfaset tussen die sintakties-stilistiese struktuuranalise en die "traditions-redaktionsgeschichtliche" fasette. By Fohrer cs en Loader kry ons, onafhanklik van mekaar, dié korrektief op die al te rigoristiese benadering van Richter deurdat hulle deurgaans in die eksegetiese proses rekening wil hou met wat Fohrer cs "Bedeutungsseite" noem en Loader "inhoudsmomente". Dit is terme wat in onderskeid met "Inhaltsseite" gebruik word. Laasgenoemde is in ' $n$ sekere sin by Richter dit wat Fohrer cs die "zusammenfassende Exegese" noem.

Dit is moontlik dat Loader, net soos in die geval van Vorster hierbo, ook nie reg begryp word oor wat hy presies met die "volgorde" van metodiese aspekte in sy metodepluralisme bedoel nie. (Vgl sy "Gekontroleerde eksegese", 6.) Miskien verdien Loader nie dieselfde kritiek wat Richter toekom nie. Die gevaar vir só 'n misverstand is egter baie groot. Eksegete soos A P B Breytenbach, Die verband tussen en die ontwikkeling in die profetiese uitsprake in die boek Hosea, diss. Universiteit van Pretoria 1979, en W H Joubert, Power and responsibility in the book Daniel, diss. UNISA 1979, pas inderdaad só 'n verdagte metodepluralisme in navolging van Loader toe. Eersgenoemde meld nie dat hy Loader navolg nie, maar wel vir Richter - ' $n$ bewering wat nie korrek is nie. Loader se invloed is egter onmiskenbaar aanwysbaar.

9. Vergelyk ook A G v Aarde, Die "betekenis" van die makarismereeks in Matteus 5. Semantiek en "Gattungsforschung" verhandeling Universiteit van Pretoria 1978, 60114. Met betrekking tot semantiese struktuuranalises wat gebied word, steun ek sterk op die artikels van A B du Toit, P J Maartens, W Nicol en J P Louw in Neotestamentica 11 (1977), The structure of Matthew 1-13. An ecploration into discourse analysis. My aanbieding verskil alleen ten opsigte van enkele "cluster" bindinge.

10. Vergelyk in dié verband veral A B du Toit, "Analysis of the structure of Mt. 4:235:48", in Neotestamentica 11 (1977), 38, C Michaelis, "Die $p$-Alliteration der Subjektsworte der ersten vier Seligpreisungen in Mt v. 3-6 und ihre Bedeutung für den Aufbau der Seligpreisungen bei Mt, Lk und Q" in NT 10 (1968), 148-161.

11. Vergelyk M Black, An Aramaic approach to the gospels and Acts, Oxford 1967, 160 e v.

12. Vergelyk byvoorbeeld die 'et, gevolg deur ' $n$ infinitivus constructus, in die meeste gevalle met $l^{e}$ wat in Prediker 3:1-9 in sestien versreëls keer op keer voorkom. Sien J A Loader, "Qohelet 3:2-8. A 'sonnet' in the Old Testament", in ZAW 81(1969), $240 \mathrm{e} \mathrm{v}$; asook sy Polar structures in the book op Qohelet, Berlyn/New York 1979,11 v; 29 e v.

13. Vgl. Die $p$ van peinōntes en die $p s$ van dipsöntes

14. A B du Toit, a $w, 38$, wys daarop dat die kappa en die gamma in die papiri dikwels uitruilbaar gebruik is.

15. Die assonansie in eirēnopoioi is des te meer opvallend wanneer in gedagte gehou word dat dit ' $n$ lekseem is wat ' $n$ hapax legomenon in Bybelse Grieks is. Vergelyk A B du Toit, $a, 38$.

16. Hiermee is dit wat onder andere deur A M Brouwer, De Bergrede, Zeist 1930, 123: H N Ridderbos, De Strekking der Bergrede naar Mattheüs, Kampen 1936, 92 en C H Dodd, "The Beatitudes: A form-critical study," in More New Testament Studies, Manchester 1968, 2, op grond van subjektiewe "inhoudsanalises" vermoed is, formeel bewys (naamlik dat vss 11-12 as 'n oorgang dien). Terselfdertyd word 'n standpunt soos dié van W Grundmann, Das Evangelium nach Matthäus (Th HK), Berlyn 1968, 119, oor die formele funksies van die negende makarisme, as ongeldig bewys. Vir Grundmann vorm al nege makarismes 'n "kunstvolle Komposition". Hy verdeel dit ook in drie dele (vss 2-6; 7-10; 11-12). Die eerste twee word gekenmerk deur die "Stichtwort" dikaiosunē. Die derde deel is vir hom slegs die herhaling van die tweede deel. R Bultmann, Die Geschichte der synoptische Tradi- 
tion, Göttingen 19797, 115 ev, se standpunt hou ook nie met die fyn komposisie van Matteus rekening soos dit duidelik op grond van die struktuuranalise na vore kom nie. Bultmann meen nl. dat vss. 11-12, vanweë die stilistiese andersheid daarvan, as 'n latere tradisie vanuit die vroeë Hellenistiese gemeente beskou moet word.

17. Die kodeks Sinaiticus, die kodeks Ephraemi en 'n paar minder belangrike teksgetuienisse laat die lesing autoi weg, terwyl die meeste, die kodeks Vaticanus en die kodeks Koridethi onder andere wel autoi lees.

18. A B du Toit $a w 38$; vergelyk ook C Michaelis, $a w, 150$.

19. Hiermee is wat die oppervlaktestruktuur van Mt. 5:3-10 betref, 'n analise gedoen wat $W$ Richter, $a w, 49-92$, die literarkritische analise en die analise van die "ornamentele" en "uiterlike" vorm noem. Vergelyk ook A G van Aarde, "'n Nuwere benadering tot 'Gattungsforschung'", in HTS jrg 36 (afl 1 en 2). In laasgenoemde artikel het ek betoog dat dit moontlik is dat betekenisaspekte wel ' $n$ rol by die sintaktiese analise kan speel. In Matt 5:3-10 was dit egter nie nodig om betekenisaspekte by die sintaktiese analise in berekening te bring nie. Vergelyk ook G Wanke, "Sprachliche Analyse", in G Fohrer cs, a w, 63 en J A Loader, "Gekontroleerde eksegese", 32.

20. J T Nielsen, Het Evangelie naar Mattheüs I (PNT), Nijkerk 1971, 88 wys ook op hierdie ringskomposisie. Vergelyk ook A B du Toit, a $w 35$ en J P Louw, "The structure of Mt. 8:1-9:35", in Neutestamentica 11 (1977), 91.

21. a $w$ 35; vergelyk ook D L Barr, "The drama of Matthew's Gospel: a reconsideration of it's structure and purpose", in Th D 24/4 (1976), 353: "The discourse of chapter 10 reaches both backwards ... and forwards ..."

22. Die kolongroepering $A$ in seksie $V I$ is die enigste wat in hierdie kategorie nie na 'n genesingswonder verwys nie. "As such it naturally ecquires some degree of emphasis: Jesus can satisfy any need. Not only infirmities, even the danger of a storm is within his authority to calm". O P Louw, "The structure of Mt 8:1-9:35:, 94).

23. Kolongroepering $A$ in seksie VII funksioneer in die dieptestruktuur as twee afsonderlike genesingswonders, en daarom as twee vertellings. Op die oppervlaktestruktuur struktureer die twee vertellings egter sintakties en komposisioneel geïntegreerd, en daarom word dit in die struktuuranalise as een vertelling weergegee. In die dieptestruktuur word eers berig gegee van 'n "gewone" genesing (die vrou wat aan bloedvloeiing gely het), en dan ' $n$ "geïntensiveerde genesing" (die opwekking van Jaïrus se dogtertjies uit die dood). Op só 'n wyse word die genesingsmag van Jesus beklemtoon, en blyk dit ook die rede te wees waarom hierdie twee vertellings in die oppervlaktestruktuur geïntegreer is. Kolongroepering A van die triologiese seksie VIII korreleer dus met A van die triologiese seksie VI. Beide die kolongroeperinge $A$ in hierdie twee seksies het onder andere 'n emfatiese funksie.

24. Hiermee is dit wat deur J Jeremias, The sermon on the mount, Athlone: Universiteit van Londen 1972, 23 op grond van 'n subjektiewe "inhoudsanalise" vermoed is, formeel bewys.

25. E A Nida en C R Taber, "The theory and practice of translation", Leiden 1974.

26. Vir volledige Nuwe-Testamentiese teksverwysings, sien A G van Aarde, Die "betekenis" van die makarismereeks, $87 \mathrm{e} \mathrm{v}$.

27. Vir voorbeelde van dieselfde tipe van onderskeidelik beide gevalle in buiteBybelse vroeë religieuse literatuur, sien $\mathrm{A} \mathrm{G}$ van Aarde, $a w, 88$.

28. J P Louw, 'Dikaiosune in the sermon on the mount", in Neotestamentica 1 (1967), 45-41.

29. Die betekenis van dikaiosune is poliseem van aard. Buite die Bergrede het dit ander betekenismoontlikhede. In Romeine 1:17, byvoorbeeld dien die lekseemkombinasie dikaiosunē theou (soos orals by Paulus) vir die betekenis van interpersoonlike gebeure met 'n forensiese gebruik wat in noue verbinding staan met die versoeningsgebeure in Christus.

30. J P Louw a w, 36.

31. J P Louw, $a w, 40$

32. Twee onsekere gevalle kan miskien by hierdie drie gevoeg word, naamlik Matteus 
6:33 waar dit tekskrities ook nie duidelik is of tön ouranōn of tou theou gelees moet word nie.

33. Vergelyk in dié verband onder andere M McNamara, Targum and Testament, Grand Rapids 1972,93 e v; 98 e v.

34. R Kassühlke, "An attempt at a dynamic equivalent translation of Basileia Tou Theou", in Bi $\operatorname{Tr}$ 25(1974), 236. Sien ook B M Newman jr. se drie artikels, "Translating 'the kingdom of God' and 'the kingdom of heaven' in the New Testament", in Bi Tr 25 (1974), 401-404; "The kingdom of God/heaven in the Gospel of Matthew", in $B i \operatorname{Tr} 27$ (1976). 427-434; "Translating 'the kingdom of God' outside the gospels", in Bi Tr 29 (1978), 225-231". Vgl ook W W Glover, "The kingdom of God in Luke, in Bi Tr 29 (1978), 231-237.

35. Vir'n dinamiese vertaling (en bespreking) van die afsonderlike makarismes in die reeks, sien B M Newman jr., "Some translational notes on the beatitudes," in Bi Tr 26 (1975), 106-120.

36. "Some translational notes," 114. (My kursivering). Sien ook sy "Translating "the kingdom of God' and 'the kingdom of heaven"', $403 \mathrm{v}$.

37. Vergelyk onder andere Str-B I, München 19265, 190; K Koch, Was ist Formgeschichte? Neue Wege der Bibelexegese, Neukirchen-Vluyn, 1974², 52; A M Brouwer, a w, 18 e v; S P J J van Rensburg, Die Messias in die saligsprekinge, Publikasie van die Universiteit van Pretoria. Nuwe Reeks 39/1967, 6. In Lukas 4:18 kry ons 'n eksplisiete verwysing daarna dat Jesus die woorde van Jesaja 62:1 e v op homself betrek het.

38. Str - B I, 190 e v.

39. G Eichholz, Auslegung der Bergpredigt, Neukirchen-Vluyn, $1970^{2}, 34$. Sien ook $W$ Grundmann, $a w, 121$.

40. W Grundmann, aw, 121.

41. J Schniewind, Das Evangelium nach Matthäus (N T D), Göttingen $1968^{2}, 41$.

42. Vergelyk B M Newman jr, "Some translational notes", 115.

43. Vir toeligting uit die Judaïca, kyk Str - B I, 195 e v. Sien ook W Grundmann, a w, 124 en S P J J van Rensburg $a w, 7$. Str - B wys op ' $n$ ander tradisie wat "redaktionsgeschichtlich" op hierdie makarisme kon ingewerk het, nl. dié van die Messiaanse vertroosting van die "treuerendes" ná die val van Jerusalem in $70 \mathrm{nC}$. vergelyk ook in dié verband, W Grundmann, $a w, 123$ nota 21.

44. W Grundmann, $a w, 124$. (My kursivering).

45. B M Newman jr, "Some translational notes", 115. (My kursivering).

46. K Koch, $a w, 52$.

47. Str - B I, 197-200. vergelyk in dié verband ook die opmerkings van S P J J van Rensburg, $a w, 7$. W Grundmann, $a w, 125$, wys daarop dat daar op grond van die Oumran-pešer op Psalm 37 afgelei kan word dat die Qumrangemeenskap hulle self as die "gemeente van die "näwim" gereken het wat wag op die redding (IV Qp Ps 37).

48. Vergelyk onder andere Henog 5:7 en Jubileë 32:18 e v.

49. Sien in dié verband J Schniewind, $a w, 44, G$ Eichholz, $a w, 41$ en S P J J van Rensburg, $a w, 8$.

50. B M Newman jr, "Some translational notes", 117 v (My kursivering).

51. G Eichholz, $a w$, 43. (Kursivering deur Eichholz.)

52. Vergelyk (Str - B I 203 e v.

53. W Grundmann, $a w, 128$.

54. J T Nielsen, $a w, 95$.

55. Vergelyk G Eichholz, $a$ w, 45: "Er (die vyfde makarisme) sagt Gottes Barmherzigkeit ... allen Barmherzigen zu, wiewohl Gottes Barmherzigkeit met menschlichter Barmherzigkeit unvergleichbar ist und mit menschlichter Barmherzigkeit nicht verdient werden kann."

56. Sien J Schniewind, $a w, 46$ en J T Nielsen, $a w, 96$

57. B M Newman jr, "Some translational notes", 118.

58. Vergelyk W Grundmann, a $w, 129$

59. G Eichholz, a w. 46

60. Str - B I, 205.

61. Vergelyk onder andere K Koch $a w, 53 ; \mathrm{G}$ Eichholz, $a w, 47 ; \mathrm{W}$ Gundmann, $a w$, 129; J T Nielsen, a w. 96. 
62. Str - B I, 206.

63. Vergelyk J Schniewind, a $w$, 46; J T Nielsen, $a w$, 97; Str - B I, 205 e v.

64. Str-B I, 205.

65. Str - B I, $207 \mathrm{v}$.

66. B M Newman jr, "Some translational notes", 118.

67. In 2 Slaw. Henog (gedateer in ongeveer dieselfde tyd as die Matteusevangelie) waar ons in hoofstuk 52:1-16'n reeks makarismes teenoor wee-uitroepe kry, lees die sesde paar (vss 11-12) soos volg: "Blessed is he who troubles those who are at peace." Vergelyk R H Charles, The apocrypha and pseudepigrapha of the Old Testament in English II, Oxford 1913, $461 \mathrm{v}$. Die oorspronklike teks is ongelukkig nie tot my beskikking vir kontrole nie. Die vertaling in Charles van hierdie gedeelte is gebaseer op die sogenaamde "volledige manuskrip" uitgegee deur A Popóv in Transactions of the historical and archaeological society of the University of Moscow, 3(1880).

68. Vergelyk W Grundmann, $a w, 131$.

69. W Grundman, $a w, 132$.

70. K Koch, a w, 53

71. J Schniewind, a $w, 48$.

72. K Koch $a w, 76$. Koch wys op die bekende parallel met 1 Petrus 4:14.

73. J Schniewind, $a w, 49$

74. S P J J van Rensburg, $a$ w, 9

75. W Grundmann, $a w, 132$.

76. Vergelyk A B du Toit, "The structure of Matthew 4:23-9:35", wat wel sódanig van mening is ..." it means that the first four beatitudess are bound together by the fact that they reflect an attitude in which the subjects in all four instances realize their need and lowliness before God. In the second four beatitudes attention is focussed more on ethical behaviour and quality."

77. Vergelyk $W$ Grundmann, $a w$, wat deurgaans in sy kommentaar op die reeks sódanige inhoudelike verhoudinge aantoon.

78. J Schniewind, $a w, 49$.

79. Aangehaal deur A M Brouwer, a $w, 227$. Vergelyk ook F Hauck, $\mathrm{s} v$ makarios $k t l$ in ThWNT IV, 370 e v.

80. G Strecker, Der Weg der Gerechtigkeit. Untersuchung zur Theologie des Matthäus (FRLANT 82), Göttingen 1962, 128, het dit al opgemerk toe hy verwys het na die "sachliche Identität der Gesetzelehre und Gottesreichpredigt ..." in die Matteusevangelie. Sien ook A B du Toit, $a w, 35$. 